ОСОБЛИВОСТІ РЕАЛІЗАЦІЇ КОМПЛЕКСНОЇ ПРОФЕСІЙНОЇ ПІДГОТОВКИ

МАЙБУТНІХ КВАЛІФІКОВАНИХ РОБІТНИКІВ НА ЗАСАДАХ МОДУЛЬНО-КОМПЕТЕНТНІСНОГО ПІДХОДУ З ВИКОРИСТАННЯМ ЕЛЕМЕНТІВ ДУАЛЬНОГО НАВЧАННЯ

\title{
FEATURES OF THE IMPLEMENTATION OF COMPREHENSIVE PROFESSIONAL TRAINING OF FUTURE SKILLED WORKERS ON THE BASIS MODULAR-COMPETENCE APPROACH USING ELEMENTS OF DUAL TRAINING
}

УДК 377.3.091.3-024.24(477)

DOI https://doi.org/10.32843/2663$6085 / 2021 / 38.22$

\section{Герлянд Т.М.,}

докт. пед. наук, старший науковий співробітник,

завідувач лабораторії технології професійного навчання Інституту професійно-технічної освіти Національної академії педагогічних наук України

\section{Нагаєв B.M.,}

докт. пед. наук, професор, профресор кафедри організації виробництва, бізнесу та менеджменту Харківського національного технічного університету сільського господарства імені Петра Василенка у статті обгрунтовано шляхи реалізації комплексної професеійної підготовки майбутніх кваліррікованих робітників на засадничих аспектах модульно-компетентнісного підходу з використанням елементів дуального навчання, який передбачає розробку: модульних програм, які відбивають основні вимоги з міждисциплінарних курсів і запланованої професійної діяльності; навчально-методичних матеріалів, інтегруючих теоретичне й професійне навчання; системи внутрішнього й зовнішнього контролю оцінки якості навчання, що застосовується з урахуванням відповідних принципів і механізмів. Кожен модуль повинен висвітлювати заплановані результати навчання, його зміст (критерії діяльності й оцінка), методи. Межі модуля за його розробки визначаються сукупністю теоретичних знань і практичних навичок, які здобувач освіти повинен продемонструвати після закінчення вивчення модуля. Критерії компетентності, яку він набуває, можуть бути розподілені на дві групи - об'єктивні й суб'єктивні (тобто зовнішні й внутрішні). Об'єктивними параметрами оцінки рівнів компетентності $\epsilon$ процесуальні особливості майбутньої просресійної діяльності (темп, швидкість, інтенсивність, обсяг); різноманітність прийомів і дій під час виконання запропонованих завдань; результативні показники діяльності - рівень та якість результатів. До суб'єктивних критеріїв рівнів компетентності можна віднести змістовні характеристики майбутньої профресійної діяльності (внутрішні спонукання, установки, мотиви поведінки); ступінь вияву мотивів, потреби діяльності. Наголошено на важливості ретельного планування та організації за модульно-компетентнісного підходу виробничої практики, щоб вона була пов'язана із чілями й завданнями профресійного навчання, для чого необхідна співпраця з роботодавцями. Здобувачам освіти повинні надаватися широкі можливості навчатися на робочому місці. Таке навчання дозволяє адаптуватися до реальності майбутньої трудової діяльності у всьому їі різноманітті, застосовувати на практичі не тільки профессійні, а й наскрізні й ключові компетентності в різноманітних просресійних ситуаціях.

Окреслено, що метою модульно-компетентнісного підходу $є$ підготовка висококваліфрікованих фрахівців, здатних працювати в постійно мінливих професіійних ситуаціях з одного боку, і готових до продовження профресійного кар'єрного зростання та освіти, - 3 іншого.
Ключові слова: дуальне навчання, модуль, компетентність, профресійна освіта, інтеграція, стандарти профресійної (профресійнотехнічноі) освіти

The article substantiates the ways of implementing complex professional training of future skilled workers on the main aspects of the modular-competence approach using the elements of dual training, which provides for the development of: modular programs that reflect the basic requirements for interdisciplinary courses and planned professional activities; teaching materials that integrate theoretical and professional training; the system of internal and external control for assessing the quality of training, is applied taking into account the relevant principles and mechanisms. Each module should cover the planned learning outcomes, its content (performance criteria and assessment) and methods. The boundaries of the module, during its development, are determined by the totality of theoretical knowledge and practical skills that the applicant for education must demonstrate at the end of the module. The criteria for the competence that he acquires can be divided into two groups - objective and subjective (that is, external and internal). Objective parameters for assessing the levels of competence are the procedural features of future professional activity (pace, speed, intensity, volume); a variety of techniques and actions when performing the proposed tasks; performance indicators - the level and quality of results. Subjective criteria for the levels of competence include the content characteristics of future professional activity (internal motives, attitudes, motives of behaviour); the degree of manifestation of motives needs of activity.

The importance of careful planning and organization with the modular-competence approach of industrial practice is emphasized, so that it is connected with the goals and objectives of vocational training, which requires cooperation with employers. Applicants for education should be given ample opportunity to learn in the workplace. Such training allows you to adapt to the reality of future work activities in all its diversity, to apply in practice not only professional, but also cross-cutting and key competencies in various professional situations.

It has been determined that the purpose of the modular-competence approach is to train highly qualified specialists who are able to work in constantly changing professional situations and are ready to continue professional career growth and education, on the other.

Key words: dual training, module, competence, professional education, integration, standards of professional (vocational) education. 
Постановка проблеми в загальному вигляді. Необхідність переходу професійної освіти до компетентнісної парадигми зумовлена потребами сучасного ринку праці, що висувають високі вимоги до кваліфікації фрахівців. Поступове входження економіки України в ринкові відносини дає чітко зрозуміти, що випускники закладів професійної (профресійно-технічної) освіти (далі - ЗП(ПТ)О), не маючи належної профресійної кваліфрікації та досвіду практичної діяльності, відчувають певні труднощі в адаптації до існуючого ринку праці. В умовах динамізму ринкових відносин професійна підготовка не може гарантувати випускникові робоче місце не тільки протягом усього життя, але й найближчим часом. Значній кількості молодих людей доводиться перенавчатися, тобто здобувати нову професію. Запобіганню цього має сприяти дуальна форма здобуття освіти, яка натепер є актуальною на часі й стає поширеною.

В Україні вже відбувається активне впровадження елементів дуальної фрорми навчання в професійну підготовку майбутніх фрахівців і здійснюється побудова стратегії вітчизняної системи такої освіти, якій притаманні певні особливості. До них, наприклад, належать: значне посилення практичної складової частини професійної підготовки майбутніх кваліфікованих робітників в умовах дуальної форми навчання; інтелектуалізація та індивідуалізація професійного навчання та його належне здійснення за умов реального виробництва; розвиток постійно діючого соціального партнерства в ЗП(ПТ)О; відповідність профресійної підготовки кваліфрікованих робітників регіональній виробничій інфрраструктурі; запровадження інституту наставництва під час здійснення дуального навчання на виробництві; створення відповідного інноваційного освітньовиробничого середовища 3П(ПТ)О [4, с. 31].

Для здійснення ефективної професійної та особистісної самореалізації майбутнього кваліфікованого робітника потрібні не тільки професійні, а й соціальні, економічні, комунікативні й інші компетентності в галузі існуючих інфрормаційно-комунікаційних технологій. Наслідком таких перетворень $€$ нагальна необхідність для системи професійної (профресійно-технічної) освіти (далі - П(ПТ)О) крокувати за постійними змінами, що відбуваються у сорері праці, гнучко й швидко реагувати на існуючу економічну ситуацію в країні, структуру ринку праці, попит роботодавців на нові компетентності фрахівців. Це вимагає суттєвого істотного підвищення конкурентоспроможності системи П(ПТ)О, створення принципово нових фрорм взаємодії із сучасним ринком праці, роботодавцями (соціальними партнерами). Тому одним із пріоритетних напрямів розвитку професійної освіти є фрормування її постійної взаємодії з виробництвом саме на засадах модульно-компетентнісного підходу, спрямованого на цільове забезпечення зв'язку процесу навчання здобувачів освіти на підприємствах, на яких їм доведеться працювати й здійснювати кар'єрне зростання в майбутньому.

Аналіз останніх досліджень і публікацій. Модульну технологію у вітчизняній системі освіти досить ґрунтовно представили у своїх чисельних дослідженнях А. Бекірова, О. Дьомін, П. Лузан, Т. Пащенко, Т. Пятничук, М. Пригодій, Л. Романишина, П. Сікорський та інші вчені.

Організацію модульної підготовки майбутніх фахівців відповідно до вимог сучасного ринку праці, модульну систему професійного навчання та його організаційно-педагогічні аспекти, дослідження дуальної форми навчання у ЗП(ПТ)О в Україні проводять С. Заславська, А. Каленський, Л. Короткова, Н. Кулалаєва, Г. Костюченко, С. Кравець, М. Михнюк, В. Ягупов.

Виділення не вирішених раніше частин загальної проблеми. Незважаючи на досить широку тематику наукових досліджень, натепер у профресійній педагогіці відбувається досить неоднозначне розуміння та трактування змісту й смислового наповнення модульного й компетентнісного підходів, які істотно доповнюють один одного, не розкрито їхніх сутнісних характеристик і технологічних аспектів формування особистості майбутніх фрахівців за умов модульного опанування профресійної діяльності.

Мета статті - розкрити особливості реалізації комплексної профресійної підготовки майбутніх кваліфрікованих робітників на засадах модульнокомпетентнісного підходу з використанням елементів дуального навчання.

Виклад основного матеріалу. За сучасних умов виникає нагальна потреба у випускниках ЗП(ПТ)О зі складних робітничих професій, оскільки управління наукомісткими автоматизованими системами з випуску складної високоточної та дороговартісної продукції стає основною профресійною фрункцією кваліфрікованих робітників.

Поняття «компетентність» досить ґрунтовно визначено в чисельних існуючих стандартах П(ПТ)О як «здатність застосовувати знання, вміння та особистісні якості для успішної діяльності в певній галузі» [7, с. 21]. Своєю чергою рівень профресійної відповідності індивідуальних показників (результатів навчання) виступає основним критерієм компетентності фрахівця для роботодавця та суспільства в цілому. Суть компетентнісного підходу полягає в тому, що в процесі освіти в людини має бути сфрормована цілісна соціально-професійна якість, що надає їй можливість успішно вирішувати виробничі завдання та взаємодіяти 3 іншими людьми. Отже, можемо констатувати, що компетентність $€$ найбільш адекватною характеристикою особистості для опису результатів його професійної діяльності, в основі якої знаходяться потреби роботодавців та існуючого сучасного ринку праці. 
Під модульно-компетентнісним підходом розуміється система побудови П(ПТ)О, метою якої $\epsilon$ формування певних ключових компетентностей здобувачів освіти. У просресійній освіті - це модель організації освітньо-виробничого процесу, в якому метою навчання виступає сукупність професійних компетентностей здобувачів освіти, а як засіб їх досягнення застосовується модульна побудова структури й змісту профресійного навчання. Використання модульно-компетентнісного підходу нині $€$ провідною вимогою сучасного стандарту П(ПТ)О, що належить до стандартів третього покоління.

Модульна побудова таких стандартів має значні переваги, зокрема:

- гнучкість (у разі необхідності існує можливість оновлювати або замінювати конкретні модулі згідно з вимогами, які висуваються до підготовки майбутніх кваліфрікованих робітників);

- можливість комбінування необхідних модулів та їх окремих одиниць для індивідуалізації професійного навчання;

- зміна процедури оцінювання - демонстрація набутих знань і вмінь за конкретним модулем (володіння комплексом відповідних компетентностей).

У межах навчальних модулів здійснюється також комплексне засвоєння теоретичних і практичних аспектів кожного виду здійснюваної профресійної діяльності. Водночас відбувається чіткий перегляд змісту теоретичних предметів щодо перерозподілу обсягу необхідних у його контексті знань, які згодом увійдуть до основ фоомування відповідних компетентностей, але разом із тим відбуватиметься постійне «відсіювання» непотрібної інсрормації [2, с. 26].

Навчальний модуль своєю чергою завжди представлений логічно завершеною частиною навчального матеріалу, певною його одиницею, водночас $€$ відносно самостійним і цілісним, маючи у своїй структурі:

- цілі навчання, комплекс знань, умінь, ставлень і досвіду (компетентностей), описаних у формі конкретних вимог, яким мають відповідати здобувачі освіти ЗП(ПТ)О із завершенням вивчення такого модуля;

- конкретний зміст у вигляді логічно завершеного блоку (блоків), які об'єднують у собі декілька тем, що вивчаються;

- технологічне й методичне «оснащення», що забезпечує освітньо-виробничий процес;

- організаційні фрорми навчання, необхідні для успішного його здійснення;

- форми контролю.

Побудова навчального модуля містить такі дії:

- визначення комплексу компетентностей, що формуються в процесі конкретного вивчення модуля;

- виділення навчальних елементів модуля змісту, встановлення внутрішньопредметних і між- предметних зв'язків у процесі його вивчення, складання викладачем опорних конспектів, схем, електронних підручників тощо;

- визначення завдань елемента модуля, фрормування в процесі його вивчення переліку конкретних компетентностей майбутнього фрахівця;

- проєктування дидактичного процесу (розроблення викладачем системи навчальних завдань, матеріалів для практичних занять, складених під рівні знань, умінь і навичок, компетентностей, підбір відповідних завдань з їх засвоєння тощо);

- розроблення позааудиторної самостійної роботи (виконання завдань за алгоритмом, різнорівневі дисреренційовані завдання проблемного характеру тощо);

- узагальнюючий елемент - висновки, основні результати;

- розроблення системи поточного й проміжного контролю різнорівневого характеру 3 використанням рейтингової системи [1, с. 19].

Метою модульно-компетентнісного підходу $€$ створення відповідних умов для фрормування комплексу компетентностей здобувачів освіти й успішності їхнього навчання, розвиток творчої пізнавальної активності й самостійності. Головна ідея такого підходу полягає у створенні належних векторів для досягнення високих результатів навчання, а також розвитку профресійної мотивації фрахівця. Саме модульна організація освітньо-виробничого процесу, постійне відстеження рівнів досягнень та оцінювання успішності навчання здобувачів освіти сприяє успішній професійній підготовці майбутніх кваліфікованих робітників [3, с. 68].

Уважаємо, що модульно-компетентнісний підхід за умови його ефективного застосування може бути засобом формування належних якостей професіоналізму майбутніх фрахівців, зокрема модульності, компетентнісності, рейтинговості, які створюють оптимальні можливості для здатності здобувачів освіти до саморозвитку, самостійного отримання навчальних знань, умінь і відпрацювання означених професійних навичок - категорій, що $€$ складовими елементами їхньої професійної компетентності.

Такий підхід також передбачає модульну побудову змісту навчання 3 конкретної професії, що орієнтує його результати - набуття особистістю необхідних ключових компетентностей для виконання трудової діяльності. Його реалізація дозволяє забезпечити гнучкість складання індивідуальних і групових програм навчання; оперативно готувати майбутніх фрахівців до потреб швидкозмінного за сучасних умов виробництва; створити адекватні умови їхньої профресійної підготовки як у закладах освіти, так і на виробництві; розробити й упровадити відповідні стандарти П(ПТ)О третього тисячоліття за принципами системності, гнучкості, прозорості, безперервності, індивідуалізації. 
Це спонукає викладачів 3П(ПТ)О до появи можливостей здійснювати постійний супровід майбутніх фрахівців із цільовими індивідуалізованими програмами, враховуючи рівень підготовленості здобувачів освіти до сприйняття навчального матеріалу, їхньої здатності й особливостей щодо його належного усвідомлення. Водночас комплексно диференціюється зміст навчального матеріалу, дозування допомоги здобувачам освіти в навчальній діяльності.

Особливо це стає помітним у дуальному навчанні, яке $€$ практико-орієнтованою фрормою організації та реалізації освітньо-виробничого процесу, коли профресійно-теоретична підготовка здійснюється в 3П(ПТ)О, а профресійно-практична - на підприємстві, безпосередньо в умовах виробництва [5]. Тобто виробниче навчання стає провідною складовою частиною професійно-практичної підготовки майбутніх фрахівців на підприємстві, яке має постійно удосконалюватися та покращуватися. Водночас майбутні фрахівці мають можливість засвоїти певні компетентності з професії та добре підготуватися до майбутньої професійної діяльності на виробництві. За такої умови успішне навчання здобувачів освіти залежить від правильної підготовки до здійснення дуальної форми навчання.

Для організації дуального навчання ЗП(ПТ)О здійснює моніторинг для відбору підприємств відповідно до переліку обов'язкових вимог, дотримання яких дає можливість закладу визначити такі, які спроможні створити належні умови для дуальної форми навчання та водночас забезпечити виконання стандарту П(ПТ)О з певної професії в повному обсязі [4, с. 161].

Однією з особливостей організації професійної підготовки майбутніх кваліфікованих робітників за дуальною фрормою навчання є їі відповідність регіональній інфраструктурі. Оскільки відповідно до затвердженої концепції реалізації державної політики у сорері профресійної (професійно-технічної) освіти України «Сучасна професійна (профресійнотехнічна) освіта» на період до 2027 року в новій моделі управління профресійною освітою розширюються повноваження саме регіональних органів влади й рад професійної освіти, керівників закладів освіти, реалізуються конкретні механізми взаємодії між центральними й місцевими органами виконавчої влади й самоврядування.

На думку розробників цієї концепції, регіональний підхід до формування кадрового потенціалу забезпечить відповідність освітніх пропозицій реальним потребам економіки, мобілізує чисельні інтелектуальні й матеріальні ресурси регіону, стимулює діагностику стану й перспектив розвитку економіки з урахуванням можливостей освітнього потенціалу певного регіону [4, с. 59].

Для забезпечення комплексу організаційних заходів, розробки навчально-планувальної доку- ментації професій, моніторингу, координації та контролю реалізації програми організації дуального навчання в ЗП(ПТ)О створюються робочі групи. До їх складу, як правило, входять: заступник директора 3 навчально-виробничої роботи, методист, старший майстер, викладачі й майстри виробничого навчання. Навчально-планувальна документація створюється на основі стандарту профресійної (профресійно-технічної) освіти 3 професії та містить: робочий навчальний план; робочі навчальні програми загальнопрофесійної та професійно-практичної підготовки; перелік і завдання для проведення контролю за рівнем засвоєння навчальних модулів; перелік кваліфрікаційних пробних робіт і завдання для їх проведення; критерії оцінювання компетентностей майбутніх кваліфікованих робітників; графріки переміщення здобувачів освіти робочими місцями; графріки контролю за проходженням їхньої профресійно-практичної підготовки на підприємствах. В установленому порядку ЗП(ПТ)О на основі стандарту П(ПТ)О розробляє, затверджує комплекс навчально-плануючої документації та погоджує її з роботодавцями.

Наприклад. у методичних рекомендаціях Л. Шевчук, Л. Джус, Г. Соленцової з розроблення навчально-планувальної та ведення облікової документації для організації навчання з професій за стандартами професійної (профресійно-технічної) освіти на основі модульно-компетентнісного підходу [6] визначено перелік напрямів вивчення здобувачами освіти навчального матеріалу, який передбачений стандартом П(ПТ)О. Для вивчення здобувачами освіти навчального матеріалу загальнопрофесійного (базового) блоку доцільно, на їхню думку, використовувати модульно-предметний підхід, який є організацією освітньо-виробничого процесу за визначеними навчальними предметами, що забезпечують належним чином здобуття переліку професійних компетентностей, які об'єднані в окремі навчальні модулі.

Також на початку роботи з розроблення робочого навчального плану створеним профільним методичним комісіям необхідно проаналізувати перелік і зміст компетентностей загальнопрофесійного (базового) блоку й об'єднати споріднені за змістом компетентності в один навчальний предмет. Отже, певна кількість компетентностей у загальнопрофесійному (базовому) блоці буде представлена декількома навчальними предметами. В окремих стандартах П(ПТ)О в базовий блок окрім загальнопрофесійних компетентностей уведені також компетентності, що належать до професійно-теоретичної складової частини. у такому випадку їх опанування рекомендовано здійснювати за принципом модульно-предметного підходу й вивчати ці компетентності як окремі навчальні предмети. Методичним комісіям спільно 3 роботодавцями необхідно розробити робочі 
навчальні програми предметів базового блоку й визначити кількість годин на їх опанування.

Для опанування здобувачами освіти професійно-теоретичною та професійно-практичною підготовками доцільно, на думку розробників методичних рекомендацій, використовувати модульно-компетентісний підхід. Як було зазначено, це організація освітнього процесу в ЗП(ПТ)О на основі компетентностей, які структуровані в окремі навчальні модулі. Для планування вивчення професійно-теоретичної підготовки профрільним методичним комісіям спільно 3 роботодавцями необхідно проаналізувати зміст усіх компетентностей модулів професійно-теоретичної підготовки, визначити кількість годин на засвоєння кожної компетентності, в тому числі тих, які засвоюються в лабораторно-практичних роботах.

Отже, організація професійної підготовки майбутніх кваліфікованих робітників у закладах профресійної (професійно-технічної) освіти на модульно-компетентнісній основі реалізується через застосування конкретних фрорм навчання (індивідуальні, парні, групові, колективні), фрорм організації навчання (уроки теоретичного й виробничого навчання), методів навчання (розповідь, пояснення, навчальна дискусія, виробничі ситуації тощо), технологій навчання, засобів навчання (навчальні посібники, картки-завдання, тести, інструктивні тексти, технологічні схеми тощо), засобів оцінювання рівнів сфрормованості ключових компетентностей майбутніх кваліфікованих робітників. Тому розроблення та запровадження робочої програмної документації на модульнокомпетентісній основі з використанням елементів дуального навчання є потужним чинником удосконалення змісту та якості підготовки майбутніх кваліфікованих робітників відповідно до вимог ринку праці й сучасних виробничих технологій.

Висновки. Реалізація комплексної профресійної підготовки майбутніх кваліфікованих робітників на засадах модульно-компетентнісного підходу 3 використанням елементів дуального навчання істотно змінює роль і функції викладачів ЗП(ПТ)О, оскільки головним стає не навчальна дисципліна, яку вони викладають, а особистість майбутнього кваліфрікованого робітника, його освітня, соціальна й профресійна компетентності, які фрормуються в процесі здійснення професійної підготовки; не навчальна дисципліна формує комплекс ключових компетентностей майбутнього фрахівця, а змістове наповнення їхньої навчальної діяльності. Щойно викладені основні шляхи реалізації профресійної підготовки майбутніх кваліфрікованих робітників із використанням елементів дуального навчання взаємопов'язані й взаємозумовлюють одне одного, посилюючи практичну спрямованість такої підготовки майбутніх фрахівців.

\section{БІБЛІОГРАФІЧНИЙ СПИСОК:}

1. Gerliand T.M. Professional training of future skilled workers in professional (vocational) education schools based on modular and competence approach. Scientific herald of the Institute of vocational education and training of NAES of Ukraine. Professional Pedagogy. 2019. № 2 (19). P. 18-23.

2. Модульно-компетентнісний підхід у підготовці кваліфікованих робітників будівельної та машинобудівельної галузей : монографія / П.Г. Лузан, В.В. Ягупов, Г.І. Лук'яненко, Т.В. Пятничук, М.І. Михнюк. Київ : Інститут професійно-технічної освіти НАПН України, 2015. 255 c.

3. Модульные технологии: проектирование и разработка образовательных программ : учебное пособие / О.Н. Олейникова, А.А. Муравьева, Ю.В. Коновалова, Е.В. Сартакова. Москва : Альфа-М, 2010. 256 c.

4. Організація дуальної форми навчання у закладах профресійної (профресійно-технічної) освіти : практичний посібник / Т.М. Герлянд, І.А. Дрозіч, Н.В. Кулалаєва, Г.М. Романова, М.М. Шимановський ; за заг. ред. Н.В. Кулалаєвої. Житомир : Полісся, 2019. 304 с.

5. Про затвердження Методичних рекомендацій щодо розроблення Державних стандартів професійно-технічної освіти 3 конкретних професій на основі компетентнісного підходу : Наказ Міністерства освіти і науки, молоді та спорту України від 26 квітня 2012 року № 522 / Міністерство освіти і науки, молоді та спорту України. URL: https://zakon.rada.gov.ua/ rada/show/v0522736-12 (дата звернення: 11.07.21).

6. Про методичний супровід упровадження стандартів професійної (професійно-технічної) освіти на основі компетентісного підходу : Лист Департаменту профр. освіти МОН України від 26 квітня 2018 року № 3-440. Навчально-методичний чентр профресійно-технічної освіти в Одеській області : вебсайт. URL: http://www.nmc.od.ua/wp-content/uploads/2018/ 05/Лист-ДПО-від-26.04.2018-№3-440.pdf (дата звернення: 14.07.21).

7. Ягупов В.В. Модульно-компетентнісний підхід до профресійної підготовки майбутніх кваліфікованих робітників будівельної та машинобудівної галузей. Науковий вісник Інституту профресійно-технічної освіти НАПН України. Профресійна педагогіка : збірник наукових праць. Київ, 2014. Вип. 7. С. 19-26. 